dr hab.inz. Marian Medwid, prof.IPS

dr Wtodzimierz, Stawecki, prof.IPS

mgr inz. Jarosław Czerwiński

mgr in $\dot{.}$.Wojciech Jakuszko

Instytut Pojazdów Szynowych ,, TABOR”

\title{
Multi-purpose rail-road tractor of the new generation
}

\begin{abstract}
The article presents an universal rail-road tractor of the third generation made on the basis of tractor CLAAS ARION 620. The structure of the tractor construction, technical and operating parameters as well as the installed devices giving it the features of multi-purpose vehicle intended for riding along the wheel road and railway tracks of normal gauge $1435 \mathrm{~mm}$ and wide tracks of $1520 \mathrm{~mm}$ are also presented.
\end{abstract}

\section{Wielozadaniowy ciągnik szynowo-drogowy nowej generacji}

\begin{abstract}
$W$ artykule zaprezentowano uniwersalny ciagnik szynowo-drogowy trzeciej generacji wykonany na bazie ciagnika rolniczego CLAAS ARION 620. Przedstawiono strukture budowy ciagnika, parametry techniczno-eksploatacyjne oraz zabudowane urzqdzenia nadajace mu cechy pojazdu wielozadaniowego przeznaczonego do jazdy po drogach kolowych $i$ torach kolejowych o normalnym rozstawie $1435 \mathrm{~mm}$ oraz na torach szerokich $1520 \mathrm{~mm}$.
\end{abstract}

\section{Wstęp}

Historia projektowania i produkcji ciagników szynowo-drogowych w Polsce ma około 30 lat tradycji. Prototyp ciagnika szynowo-drogowego zbudowano w IPS TABOR na bazie ciagnika rolniczego URSUS, jedynej marki ciągników dostępnych w owym czasie na rynku polskim. Pierwsze dwa ciagniki szynowodrogowe dostarczono do Warszawskiego Metra przed uruchomieniem pierwszej linii. Jeden z ciagników był wykorzystywany na stacji postojowej Kabaty do przeciagania wagonów $\mathrm{z}$ hali postojowej na tor próbny wyposażony $\mathrm{w}$ zasilanie trzecią szyną, na którym prowadzono jazdy próbne wagonów przed wdrożeniem do eksploatacji.

Drugi ciagnik szynowo-drogowy wyposażono w podnośnik koszowy za pomocą którego wykonywano obsługę latarni oświetlających teren stacji postojowej oraz czyszczenie szklanych świetlików dachowych hali.

Wykonano kilka sztuk ciaggników szynowodrogowych na bazie ciagników URSUS 1212 i 1224, które znalazły zastosowanie na bocznicach kolejowych do przetaczania wagonów o łącznej masie do 400 ton.

Kolejnym etapem rozwoju było zastosowanie jako ciagnnika bazowego, ciągników rolniczych marki CRYSTAL 120, 121 oraz CRYSTAL ORION 13. Ciagniki posiadały napęd na dwie osie, co pozwoliło zwiększyć właściwości trakcyjne ciągników szynowo-

\section{Introduction}

The history of designing and production of railroad tractors in Poland is around 30 years of tradition. The prototype of the rail-road tractor was built in IPS TABOR based on the URSUS tractor, the only brand of tractors available at that time on the Polish market. The first two rail-road tractors were delivered to the Warsaw Metro before starting of the first line. One of the tractors was used on the parking station Kabaty for towing the wagons from the parking hall on the test track equipped with power supply of the third rail, on which the test rides of wagons were carried out before the implementation to the operation.

The second rail-road tractor was equipped with the basket lift by means of which the service of lamp posts lighting the parking area of the station and cleaning the glass skylights of hall were performed.

A few pieces of rail-road tractors on the basis of tractors URSUS 1212 and 1224, which found the use on the railway sidings for shunting of wagons with a total weight of 400 tons, were made.

The next stage of development was using as the base tractor the agricultural tractors of CRYSTAL 120, 121 and CRYSTAL ORION 13 brands. The tractors had two driving axles, which allowed to increase the traction characteristics of rail-road tractors. In addition, in the option the pneumatic railway brake was offered, so that the maximum mass of the coupled wagons up increased from $400 \mathrm{t}$ of the previous 
drogowych. Dodatkowo w opcji oferowano pneumatyczny hamulec kolejowy, dzięki czemu maksymalna masa zespołu doczepionych wagonów wzrosła z $400 \mathrm{t}$ poprzedniej wersji do $\sim 800$ t. Oprócz standardowego rozstawu rolek, ciagnik był oferowany $\mathrm{z}$ szynowym układem jezdnym $\mathrm{z}$ rozstawem na szeroki tor jak również, wszędzie tam gdzie na bocznicach kolejowych występują dwa rodzaje torów, ze zmiennym rozstawem rolek prowadzących.

Po wieloletnim okresie bazowania na ciagniku CRYSTAL ORION na polskim rynku pojawiły się inne nowoczesne marki ciągników rolniczych, z których wymagania do adaptacji na ciągnik szynowo-drogowy w najszerszym zakresie parametrów technicznoeksploatacyjnych układów mechanicznych, napędów hydraulicznych oraz układów sterowania, spełnia ciągnik rolniczy CLAAS ARION 620.

\section{Rzeczywisty model strukturalny ciągnika}

\subsection{Ciągnik przystosowany do eksploatacji na torze normalnym $1435 \mathrm{~mm}$}

Ciagnik szynowo-drogowy na tor normalny przedstawiony na rys. 1,2 jest zbudowany z ciagnika bazowego 1 wyposażonego w przedni układ pociagowozderzny $\underline{\mathbf{2}}$, tylny układ pociagowo-zderzny $\underline{\mathbf{3}}$, wyposażony w obrotowy zderzak $\underline{4}$, szynowy układ jezdny przedni i tylny $\underline{\mathbf{5}}$, układ hydrauliczny $\underline{\mathbf{6}}$ do zasilania siłowników $\underline{7}$ szynowego układu jezdnego $\underline{\mathbf{5}}$, sprężarki powietrza $\underline{\mathbf{8}}$, zbiorników powietrza $\underline{\mathbf{9}}$, układu sterowania $\underline{10}$ i 11 oraz węży hamulcowych $\underline{12}$ układu hamulcowego do hamowania składu doczepionych wago-

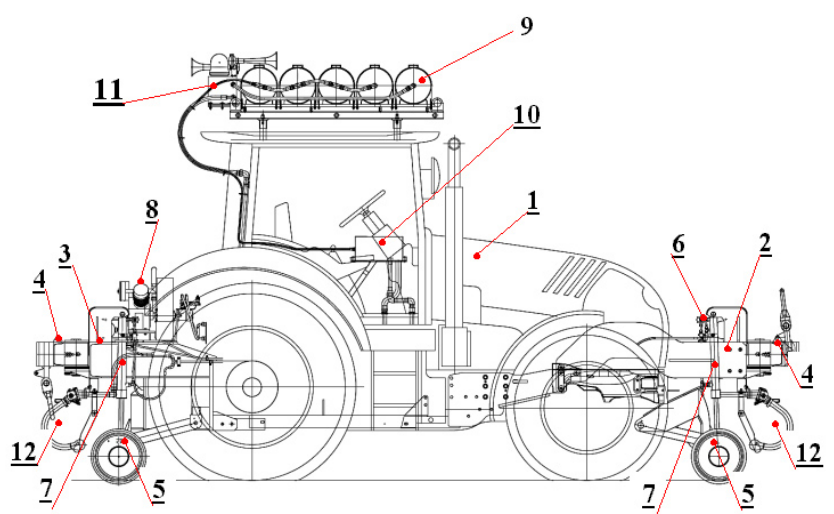

Rys.1. Ciagnik na tor normalny - widok $\mathrm{z}$ boku

Fig.1. Tractor for the normal track - side view

Ciagnik na rys. 2 (widok z góry) przedstawiono bez korpusu silnika oraz układu napędowego, natomiast pokazano konstrukcję ramową ciagnika $\underline{\mathbf{1 3}}$ oraz przedni wspornik 14 do którego zamocowano za pomoca połączeń śrubowych, przedni układ pociaggowozderzny $\underline{2}$, związany z przednim wspornikiem $\underline{14}$ oraz konstrukcją ramową 13 za pomocą dwóch belek podłużnych 15 łączących przedni układ pociagowo- version to $\sim 800 \mathrm{t}$. Apart the standard rollers spacing, the tractor with the running gear system with the spacing for the wide track was offered, as well as with the variable spacing of the guide rollers wherever on the railway sidings there are two types of tracks.

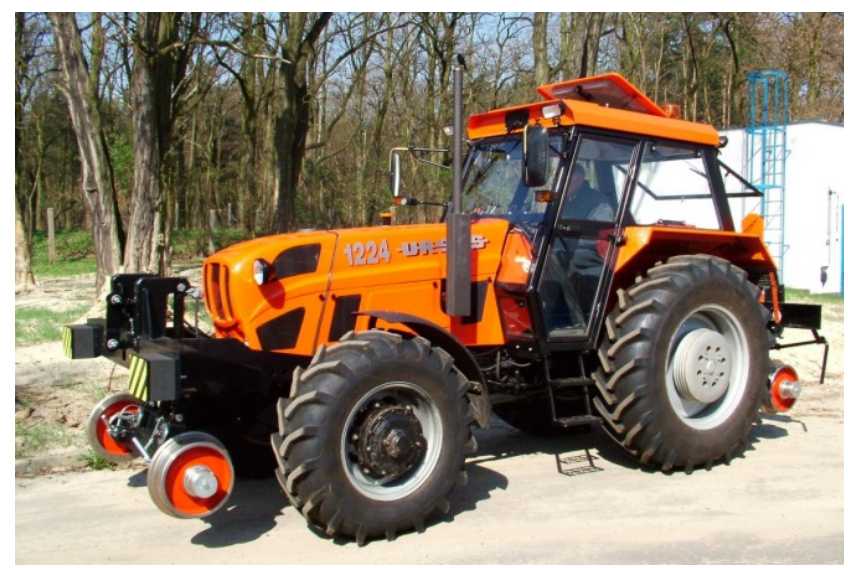

Fot. 1. Ciagnik URSUS

Photo 1. Tractor URSUS

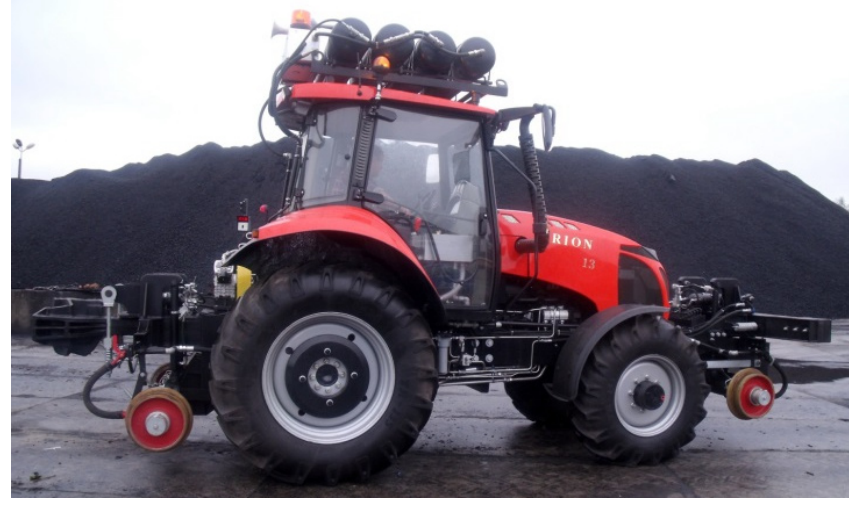

Fot. 2. Ciagnik CRYSTAL - ORION

Photo 2. Tractor CRYSTAL - ORION

After many years of basing on the tractor CRYSTAL ORION on the Polish market, the other modern brands of agricultural tractors appeared, which requirements to adapt to the rail-road tractor with the widest range of technical-operational parameters of mechanical systems, hydraulic drives and control systems are met by the agricultural tractor CLAAS ARION 620 .

\section{Real structural model of tractor}

\subsection{Tractor adapted to operation on a normal track of 1435 mm}

The rail-road tractor on the normal track presented in Fig. 1, 2 is made from the base tractor 1 equipped with the front draw and buffing gear system $\underline{\mathbf{2}}$, the rear draw and buffing gear system $\underline{\mathbf{3}}$, equipped with the rotary buffer $\underline{4}$, the front and rear rail running gear systems $\underline{\mathbf{5}}$, the hydraulic system $\underline{\mathbf{6}}$ for powering the actuators $\underline{\mathbf{7}}$ of rail running gear system $\underline{\mathbf{5}}$, the air compressors $\underline{\mathbf{8}}$, the air tanks $\underline{\mathbf{9}}$, the control system $\underline{\mathbf{1 0}}$ 


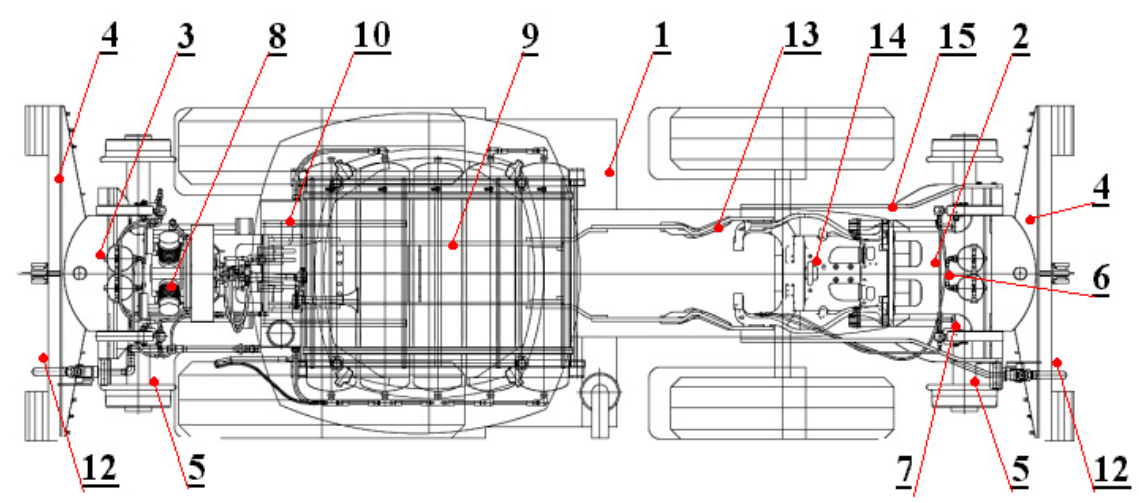

Rys. 2. Ciagnik na tor normalny - widok z góry (widok bez korpusu silnika oraz układu napędowego)

zderzny z konstrukcją ramową $\underline{\mathbf{1 3}}$ ciagnika w miejscu gdzie konstrukcja ciagnika jest przystosowana do przejmowania dużych obciążeń wzdłużnych.

Przedni układ pociagowo-zderzny wraz z przednim wspornikiem i konstrukcją ramową ciągnika poddano symulacyjnym badaniom wytrzymałościowych na działanie sił wzdłużnych o wartościach: ściskanie 300 $\mathrm{kN}$ i rozciaganie $150 \mathrm{kN}$, których wyniki zostana zaprezentowane oddzielnie w kolejnej publikacji.

Mocowanie przedniego układu pociagowo-zderznego do wspornika $\underline{14}$ oraz konstrukcji ramowej $\underline{13}$ ciagnika pokazano $\mathrm{w}$ ujęciu perspektywicznym na rys. 3, a tylnego układu pociagowo-zderznego na rys. 4.

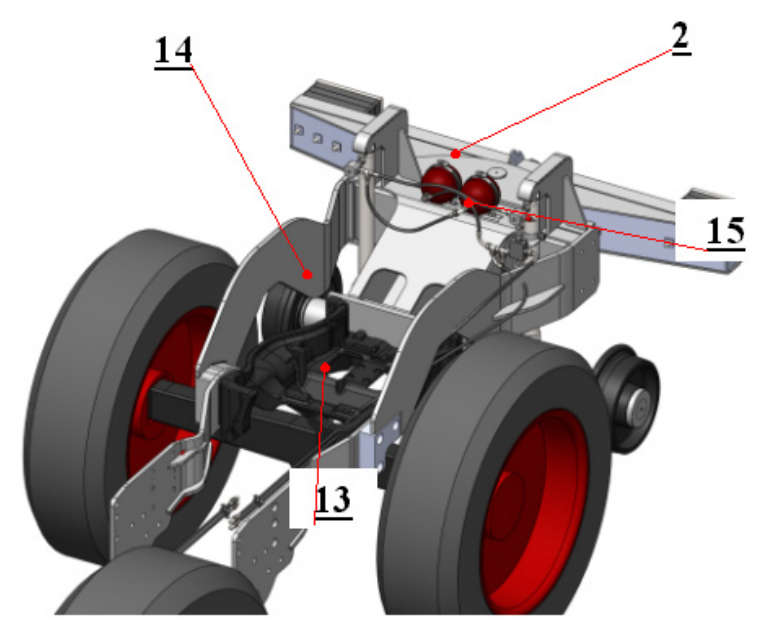

Rys. 3. Mocowanie przedniego układu pociągowo-zderznego

Fig. 3. Mounting of the front draw and buffing gear system

\subsection{Ciągnik przystosowany do eksploatacji na torze normalnym $1435 \mathrm{~mm}$ i torze szerokim $1520 \mathrm{~mm}$}

$\mathrm{Na}$ rys. 5 zilustrowano konstrukcję ciagnika przystosowanego do jazdy po torze normalnym i szerokim.
Fig. 2. Tractor for the normal track - top view (view without the body of engine and the driving system)

and $\underline{11}$ and brake hoses $\underline{\mathbf{1 2}}$ of braking system for braking the set of coupled wagons up.

Tractor in Fig. 2 (top view) is presented without the body of engine and the driving system, while it is shown the frame construction of tractor $\underline{\mathbf{1 3}}$ and the front bracket $\underline{14}$ to which the front draw and buffing gear system is fastened using the screw connections $\underline{\mathbf{2}}$, connected with the front bracket $\underline{\mathbf{1 4}}$ and the frame construction $\underline{\mathbf{1 3}}$ using two longitudinal beams $\underline{\mathbf{1 5}}$ connecting the front draw and buffing gear system with the frame construction $\underline{\mathbf{1 3}}$ of the tractor where the tractor construction is adapted to absorb the high longitudinal loads.

The front draw and buffing gear system with the front bracket and the frame construction of tractor was subjected to simulation of strength tests on action of longitudinal forces of values: compression of $300 \mathrm{kN}$ and tension of $150 \mathrm{kN}$, the results of which will be presented separately in the next publication.

Mounting of the front draw and buffing gear system to the bracket $\underline{14}$ and the frame construction $\underline{13}$ of tractor are presented in perspective in Fig. 3, and the rear draw and buffing gear system in Fig. 4.

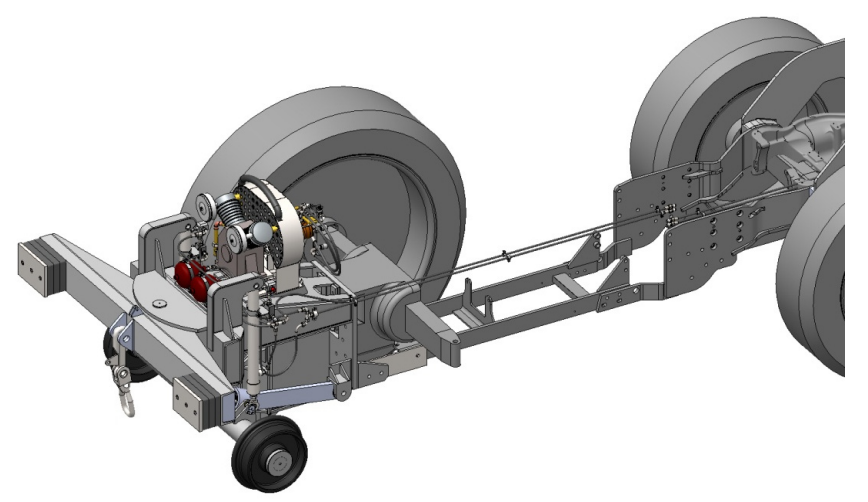

Rys. 4. Zabudowa tylnego układu pociagowo-zderznego

Fig. 4. Installation of the rear draw and buffing gear system 


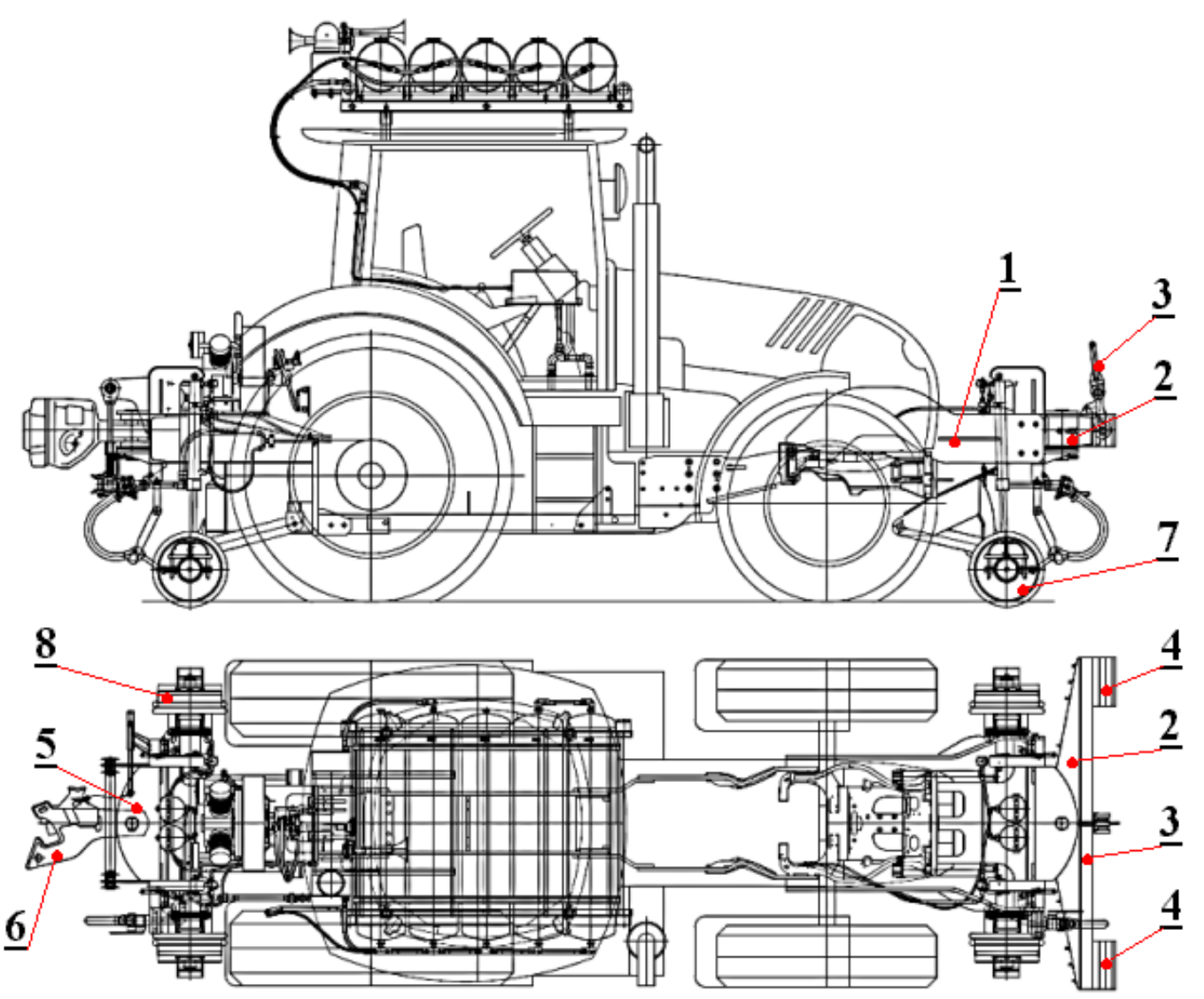

Rys. 5. Ciagnik szynowo-drogowy na tor normalny i szeroki

Fig. 5. Rail-road tractor for the normal and wide tracks

Założenia projektowe dla ciagnika $\mathrm{w}$ tej wersji wykonania przewiduja przeciaganie wagonów po torze normalnym za pomoca przedniego układu pociagowozderznego $\underline{\mathbf{1}}$, który wyposażono w zderzakową belkę obrotową $\underline{\mathbf{2}}$ zaopatrzoną w hak pociagowy $\underline{\mathbf{3}}$ oraz gumowe amortyzatory zderzakowe $\underline{4}$.

Przeciaganie wagonów na torze szerokim jest realizowane za pomoca tylnego układu pociagowozderznego $\underline{\mathbf{5}}$, w którym zabudowano centralny sprzęg samoczynny $\underline{\mathbf{6}}$ typu SA3. Ciagnik wyposa-żono w szynowy układ jezdny $\underline{\mathbf{Z}}$ z osią o zmiennym rozstawie rolek prowadzących $\underline{\mathbf{8}}$.

\subsection{Zestaw kołowy ze zmiennym rozstawem rolek prowadzących}

Zestaw kołowy zilustrowano na rys. 6, który skompletowano z następujących głównych zespołów i detali:

- osi zestawu $\underline{1}$

- rolki prowadzącej $\underline{\mathbf{2}}$

- mechanizmu przestawiania rozstawu rolek $\underline{\mathbf{3}}$

- wspornika prowadzenia osi $\underline{4}$

- wahaczy $\underline{\mathbf{5}}$ mocowania osi zestawu

- mechanizmu blokowania $\underline{\mathbf{6}}$ pozycji rolki prowadzącej

- przegubów połączenia wahaczy z osią $\underline{7}$

\subsection{Tractor adapted to operation on a normal track of $1435 \mathrm{~mm}$ and wide track of $1520 \mathrm{~mm}$}

The construction of tractor adapted to operation on the normal and wide tracks is illustrated in Fig. 5.

The design assumptions for the tractor in this version of making provide for towing the wagons on the normal track using the front draw and buffing gear system $\underline{\mathbf{1}}$, which is equipped with the buffer rotary beam $\underline{\mathbf{2}}$ provided with a towing hook $\underline{\mathbf{3}}$ and the buffer rubber shock absorbers $\underline{4}$.

Towing the wagons on the wide track is realized using the rear draw and buffing gear system $\underline{\mathbf{5}}$, in which the central automatic coupler $\underline{\mathbf{6}}$ of type SA3 was installed. The tractor was equipped with the rail running gear system $\underline{7}$ with the axle of the changeable spacing of the guide rollers $\underline{\mathbf{8}}$.

\subsection{Wheelset with the changeable spacing of guide rollers}

The wheelset is illustrated in Fig. 6. It is completed from the following main assemblies and components: 
- mechanizmu przesuwnego mocowania rolki prowadzącej na czopie osi $\underline{\mathbf{8}}$

- wsporników mocowania cylindrów hydraulicznych $\underline{9}$.

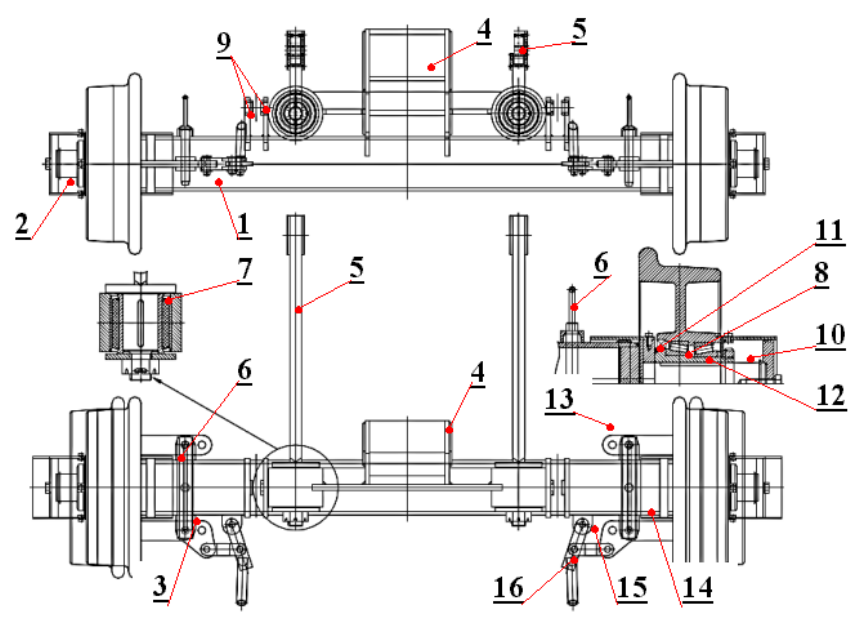

Rys. 6. Zestaw kołowy ze zmiennym rozstawem rolek prowadzących

Fig. 6. Wheelset with the changeable spacing of guide rollers

Mocowanie i łożyskowanie rolki prowadzącej na wydłużonym czopie osi $\underline{\mathbf{1 0}}$ zrealizowano za pośrednictwem tulei przesuwnej 11 zabezpieczonej przed obrotem względem czopa osi wpustem $\underline{\mathbf{1 2}}$.

$\mathrm{Z}$ tuleją przesuwną 11 związane są dwa płaskowniki $\underline{13}$ i $\underline{14}$ z wykonanymi dwoma otworami w każdym płaskowniku oddalonymi od siebie o różnicę rozstawu rolek prowadzących na torze szerokim i normlanym tj. o wartość $1520-1435=85 / 2=42,5 \mathrm{~mm}$. W płaskowniku zewnętrznym 14 wyko-nano dodatkowo trzeci otwór, w którym zamocowano cięgło $\underline{\mathbf{1 5}}$ mechanizmu przestawiania rozstawu rolek. Przemieszczając odpowiednio $\mathrm{w}$ lewo lub $\mathrm{w}$ prawo dźwignią 16 mechanizmu przestawiania rozstawu rolki następuje przemieszczenie rolki prowadzącej odpowiednio do rozstawu dla toru normalnego lub szerokiego.

Po wyborze odpowiedniego rozstawu rolek należy je zablokować w tym położeniu za pomocą mechanizmu blokowania 6. Przestawianie położenia rolek prowadzących wykonuje się ręcznie, dla każdej rolki oddzielnie, przy uniesionej osi zestawu kołowego.

\section{Glówne zespoły urządzeń pociągowo-zderz- nych}

\subsection{Zespół przedniego układu pociągowo-zderz- nego}

Zespół nośny przedniego układu pociągowozderznego rys. 7 wykonano w postaci spawanej konstrukcji skrzyniowej $\underline{\mathbf{1}}$ belki poprzecznej $\underline{\mathbf{2}}$ i płyty mocowania $\mathbf{3}$.

Podstawową konstrukcję nośną wyposażono w odpowiednie wsporniki:

- wspornik 4 mocowania obrotowej belki zderzakowej lub sprzęgu SA3
- wheelset axle 1

- guide roller $\underline{\mathbf{2}}$

- mechanism of changing the rollers spacing $\underline{\mathbf{3}}$

- bracket supporting the axle $\underline{4}$

- suspensions arms $\underline{\mathbf{5}}$ of wheelset axle mounting

- locking mechanism $\underline{\mathbf{6}}$ of guide roller position

- articulated joints of connection of suspension arms with axle $\underline{7}$

- sliding mechanism of mounting of guide roller on pivot $\underline{\mathbf{8}}$

- brackets of mounting of hydraulic cylinders $\underline{9}$.

Fixing and bearing of the guide roller on the elongated pivot $\underline{\mathbf{1 0}}$ was implemented through the sliding sleeve $\underline{11}$ secured against rotation relative to the axle pivot with the groove $\mathbf{1 2}$.

Two flat bars $\underline{\mathbf{1 3}}$ and $\underline{\mathbf{1 4}}$ with two holes made in each flat bar spaced from each other by a difference of spacing of the guide rollers on the wide and normal tracks i.e. by the value of 1520 $1435=\mathrm{mm}$ are connected with the sliding sleeve 11. In the external flat bar 14 the third hole was made, in which is fastened the $\operatorname{rod} \underline{\mathbf{1 5}}$ of mechanism of changing the rollers spacing. Appropriately moving the lever $\underline{\mathbf{1 6}}$ of the mechanism of changing the roller spacing to the left or right, the movements of the guide roller follows according to the normal or wide track gauge.

After selecting the appropriate spacing of the rollers, they should be locked in that position by the locking mechanism ‥ Changing of the position of the guide rollers is performed manually, for each roller separately at the raised wheelset axle.

\section{Main units of the draw and buffing gear devices}

\subsection{Unit of the front draw and buffing gear system}

The supporting unit of the front draw and buffing gear system Fig. 7 was made in the form of the welded box construction $\underline{\mathbf{1}}$, crossbeam $\underline{\mathbf{2}}$ and fixing board $\underline{3}$.

The basic supporting unit was equipped with the suitable brackets:

- bracket $\underline{4}$ of fastening of the rotary buffer beam or coupler SA3

- brackets $\mathbf{5}$ for mounting the hydraulic actuators of the rail running gear system

- brackets $\underline{\mathbf{6}}$ of fastening of the suspension arms of the wheelset axle

- brackets $\underline{7}$ of axle guides of the rail running gear system.

The box construction of the draw and buffing gear system is screwed to the supporting units of the tractor by using the screw connections of the fixing plate $\underline{\mathbf{3}}$ 
- wsporniki $\underline{\mathbf{5}}$ do zamocowania siłowników hydraulicznych szynowego układu jezdnego

- wsporniki $\underline{\mathbf{6}}$ mocowania wahaczy osi zestawu kołowego

- wsporniki 7 prowadnic osi szynowego układu jezdnego.

Konstrukcja skrzyniowa układu pociagowo-zderznego jest przykręcona do ustrojów nośnych ciągnika za pomoca połączeń śrubowych płyty mocowania $\underline{\mathbf{3}} \mathrm{i}$ powierzchni czołowej wspornika osi $\underline{14}$ rys. 3 oraz podłużnych belek nośnych 15 rys. 3 zamocowanych do powierzchni bocznych belki poprzecznej 2 rys. 7 oraz bocznych belek 13 rys. 3 konstrukcji ramowej ciagnika.

\subsection{Zespól tylnego układu pociągowo-zderznego}

Na rys. 8 pokazano tylny moduł układu pociagowozderznego, który jest złożony z konstrukcji skrzyniowej $\underline{\mathbf{1}}$ oraz belki poprzecznej $\underline{\mathbf{2}}$. Konstrukcję skrzynkową 1 w tylnej części wyposażono w płytę mocująca $\underline{\mathbf{3}} \mathrm{z}$ odpowiednimi otworami przygotowanymi do połączenia śrubowego skrzyni tylnego układu pociagowo-zderznego $\mathrm{z}$ pionową ścianą tylnego mostu ciągnika bazowego (rys. 4).

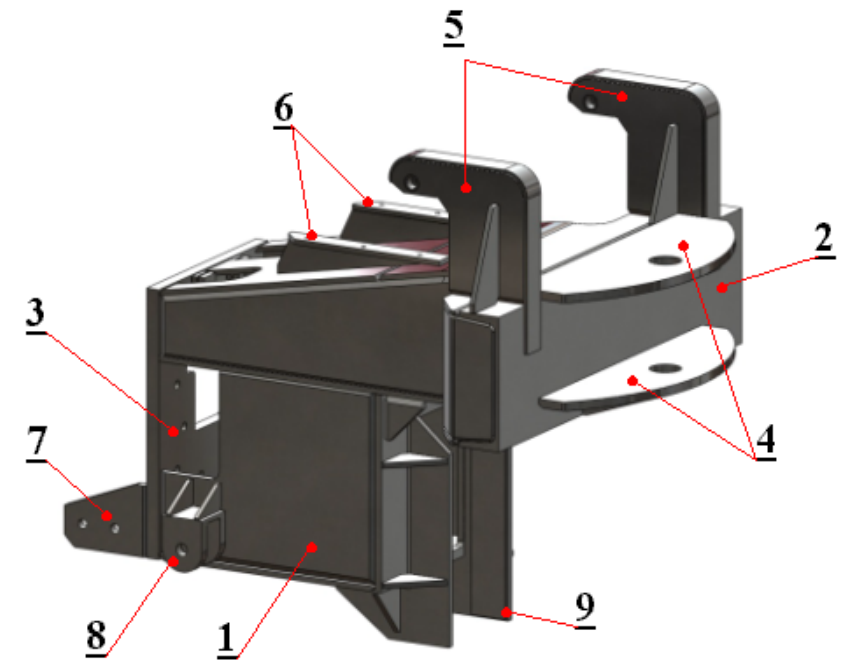

Rys. 8. Podstawowy zespół nośny tylnego układu pociągowozderznego

Fig. 8. Basic supporting unit of the rear draw and buffing gear system

$\mathrm{Na}$ podstawowej konstrukcji nośnej umieszczono odpowiednie wsporniki do zamocowania zespołów przewidzianych do montażu kompletnego zespołu tylnego układu pociagowo-zderznego.

W przedniej części konstrukcji nośnej do belki poprzecznej 2 przyspawano płyty wspornikowe $\underline{4}$ do mocowania obrotowej belki zderzakowej lub zamiennie sprzęgu centralnego SA3.

Do górnej części belki zamocowano wsporniki $\underline{\mathbf{5}}$ przeznaczone do montażu siłowników hydraulicznych szynowego układu jezdnego. Na górnej pły- and the front surface of axle bracket $\underline{14}$ Fig. 3 and the longitudinal supporting beams 15 Fig. 3 fastened to the side surfaces of the crossbeam $\underline{\mathbf{2}}$ Fig. 7 as well as the side beams $\underline{\mathbf{1 3}}$ Fig. 3 of the frame construction of tractor.

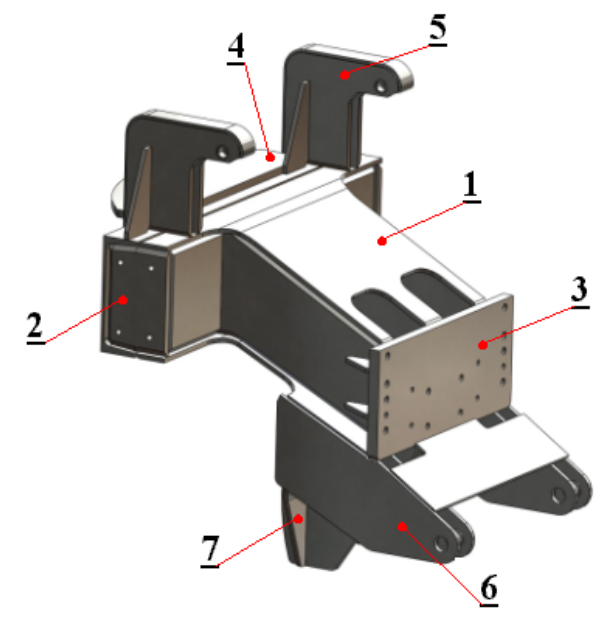

Rys. 7. Podstawowy zespół nośny przedniego układu pociągowozderznego

Fig. 7. Basic supporting unit of the front draw and buffing gear system

\subsection{Unit of the rear draw and buffing gear system}

In Fig. 8 it is presented the rear module of raw and buffing gear system, which is consisted of the box construction $\underline{\mathbf{1}}$ and the crossbeam $\underline{\mathbf{2}}$. The box construction $\underline{1}$ in the rear part is equipped with the fixing plate $\underline{\mathbf{3}}$ with the suitable holes prepared for the screw connection of the box of rear draw and buffing gear system with the vertical wall of the rear bridge of the basic tractor (Fig. 4).

On the basic supporting construction the appropriate brackets are put for fastening the assemblies intended to install the complete rear draw and buffing gear system.

In front part of the supporting construction two bracket plates $\underline{\mathbf{4}}$ are welded to the crossbeam $\underline{\mathbf{2}}$ for fastening the buffer rotary beam or alternatively the central coupler SA3.

To the upper part of the beam the brackets $\underline{\mathbf{5}}$ are fastened intended to install the hydraulic actuators of the rail running gear system. On the upper board of the box construction the brackets $\underline{\mathbf{6}}$ are put for fastening the compressor of the braking system. In the bottom part of the fixing board $\underline{\mathbf{3}}$ the brackets $\underline{\mathbf{7}}$ are intended to connect the frame construction of tractor with the box construction, and to the side walls of construction the brackets $\underline{\mathbf{8}}$ are mounted which are intended to install the suspension arms of the rail running gear system and the fork brackets $\underline{9}$ for supporting the axle of wheelset.

\section{Working devices of the rail-road tractor}

In the basic design the tractor is designed for shunting of wagons on the railway sidings. At the 
cie konstrukcji skrzyniowej umieszczono wsporniki $\underline{6}$ do mocowania sprężarki układu hamulcowego. W dolnej części płyty mocującej $\underline{\mathbf{3}}$ przewidziano wsporniki $\underline{7}$ do połączenia konstrukcji ramowej ciagnika $\mathrm{z}$ konstrukcją skrzyniowa, a do ścian bocznych konstrukcji zamocowano wsporniki $\underline{\mathbf{8}}$ przeznaczone do mocowania wahaczy szynowego układu jezdnego oraz wsporniki widłowe 9 prowadzenia osi zestawu kołowego.

\section{Urządzenia robocze ciągnika szynowo-drogo- wego}

W podstawowym wykonaniu ciagnik jest przeznaczony do pracy manewrowej z wagonami na bocznicach kolejowych. Na żądanie zamawiającego ciągnik może być wyposażony w zaczep do mocowania przyczepy drogowej.

$\mathrm{W}$ prezentowanym artykule przedstawiono ciagnik $\mathrm{w}$ wykonaniu wielofunkcyjnym przez przystosowanie go do zabudowy następujących urządzeń roboczych:

- lemieszowego pługa odśnieżnego

- posypywarki piasku lub soli

- opryskiwacza do zwalczania chwastów.

\subsection{Zabudowa pługa lemieszowego}

Na rys. 9 pokazano przód ciagnika z zabudowanym pługiem lemieszowym $\underline{1}$. Aby przystosować ciagnik do zabudowy pługa został on wyposażony w odpowiedni wspornik $\underline{2}$ z płytą czołową $\underline{\mathbf{3}}$, do której zamocowano płytę pługa $\underline{4}$. Wspornik $\underline{\mathbf{2}}$ zaopatrzono w cięgła $\mathbf{5}$, których zadaniem jest przeniesienie sił wzdłużnych z lemiesza na konstrukcję układu pociągowo-zderznego. Lemiesz pługa zamocowano do płyty pługa za pośrednictwem trzypunktowego przegubowego wahacza $\underline{6}$.

Do podnoszenia i opuszczania lemiesza zastosowano siłownik hydrauliczny $\underline{7}$ sterowany z kabiny kierowcy. Do zmiany kierunku odgarniania śniegu (na prawą lub lewą stronę) zastosowano ręcznie przekładane cięgło $\underline{\mathbf{8}}$.

\subsection{Zabudowa posypywarki piasku}

Zabudowę posypywarki piasku w tylnej części ciagnika zilustrowano na rys. $10 \mathrm{i} 10$ '.

Mocowanie posypywarki $\underline{\mathbf{1}}$ do konstrukcji tylnego układu pociagowo-zderznego zrealizowano za pomocą wspornika $\underline{\mathbf{2}}$ zamontowanego w miejscu mocowania belki zderzakowej lub sprzęgu samoczynnego oraz dwóch cięgieł $\underline{\mathbf{3}}$ zabudowanych do wsporników $\underline{4}$ przyspawanych do belki poprzecznej układu pociągowo-zderznego i czopów $\underline{\mathbf{5}}$ związanych $\mathrm{z}$ ramą pospawarki 1. Obrót talerza rotacyjnego posypywarki zrealizowano za pomocą napędu silnikiem hydraulicznym $\underline{\mathbf{6}}$ zasilanym z hydrauliki siłowej ciagnika przewodami $\mathbf{7}$ połączonymi z instalacją hydrauliczną ciagnika za pomocą szybkozłączy $\underline{\mathbf{8}}$. request of the customer, the tractor may be equipped with a hook for attaching the road trailer.

The article presents the tractor in the multifunction implementation by adapting it to fasten the following working devices:

- share plough for snow removal

- the sand or salt spreader

- sprayer for weed-control.

\subsection{Assembly of the share plough}

Fig. 9 presents the front of tractor with the fastened share plough $\underline{\mathbf{1}}$. In order to adapt the tractor to fasten the plough it is equipped with the suitable bracket $\underline{\mathbf{2}}$ with the front plate $\underline{3}$, to which plough plate $\underline{4}$ is attached. The bracket $\underline{\mathbf{2}}$ is provided with the pull rods 5, whose task is to transmit the longitudinal forces from the share onto the construction of draw and buffing gear system. The share of plough is fastened to the plough plate through the three-point suspension articulated arm $\underline{\mathbf{6}}$.

For lifting and lowering of the share, the hydraulic actuator $\underline{7}$ is used which is controlled from the driver cab. In order to change the direction of removing the snow (to the right or left side) the pull rod adjusted manually is used $\underline{\mathbf{8}}$.

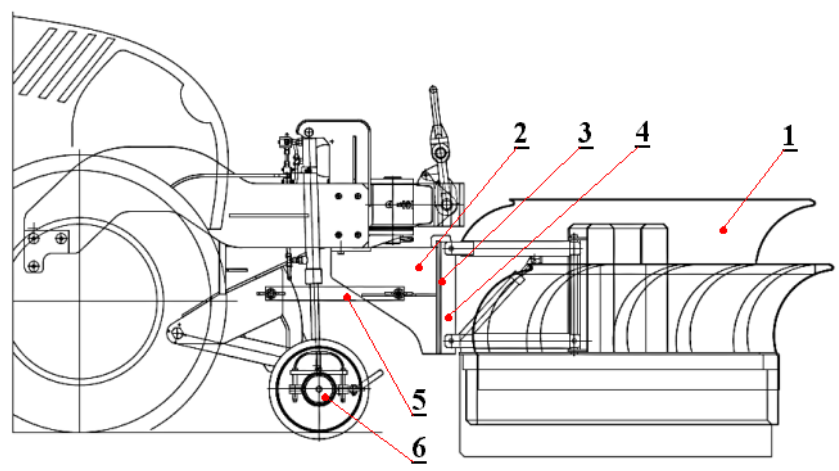

Rys. 9. Zabudowa pługu lemieszowego (widok z boku)

Fig. 9. Assembly of the share plough (side view)

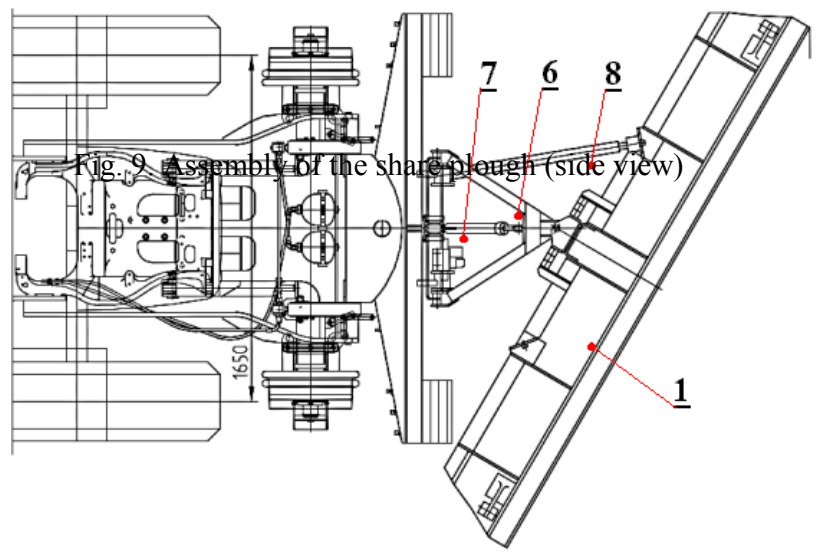

Rys. 9'. Zabudowa pługa lemieszowego (widok z góry)

Fig. 9'. Assembly of the share plough (top view) 


\subsection{Zabudowa opryskiwacza do zwalczania chwa- stów}

Rys. 11 przedstawia opryskiwacz do chwastów zamontowany na tylnym układzie pociagowozderznym. Metoda mocowania opryskiwacza pozostaje taka sama jak dla posypywarki. System napędu pompy opryskiwacza również został zrealizowany za pomocą silnika hydraulicznego. Zastosowano tzw. unifikację przyłączy mechanicznych i hydraulicznych dla obu urządzeń roboczych, do montażu których przystosowano tylny układ pociagowo-zderzny ciągnika.

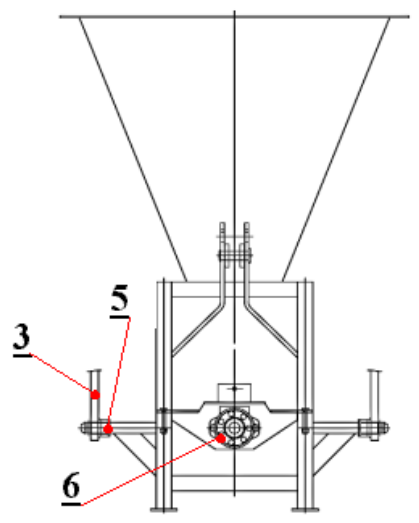

Rys. 10'. Zabudowa posypywarki piasku (widok z tyłu na ramę posypywarki)

Fig. 10'. Assembly of the sand spreader (rear view of the preader frame)

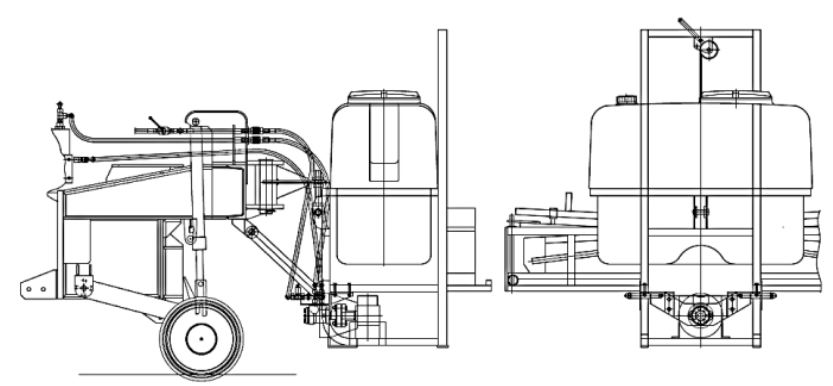

Rys. 11. Zabudowa opryskiwacza Fig. 11. Assembly of the sprayer

\section{Parametry techniczne ciągnika}

5.1. Dane charakterystyczne ciągnika bazowego

\subsection{Assembly of the sand spreader}

Assembly of the sand spreader in the rear part of the tractor is illustrated in Fig. 10 and 10.

Assembling of the spreader $\underline{1}$ to the construction of the rear draw and buffing gear system is realized using the bracket $\underline{\mathbf{2}}$ installed at the place of fixing the buffer beam or automatic coupler and two pull rods $\underline{\mathbf{3}}$ fastened to brackets $\underline{4}$ welded to the crossbeam of the draw and buffing gear system and pivots $\underline{\mathbf{5}}$ connected with the frame of spreader $\underline{1}$. Rotation of the rotary plate of spreader is made using the hydraulic motor drive $\underline{\mathbf{6}}$ powered pipes from the force hydraulics of the tractor $\underline{7}$ connected with the hydraulic installation of tractor through the quick coupling $\underline{\mathbf{8}}$.

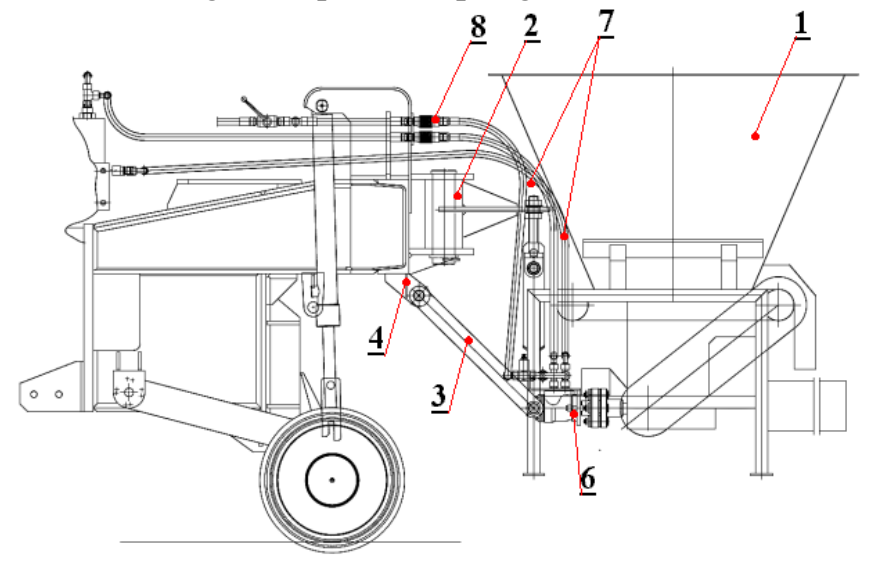

Rys. 10. Zabudowa posypywarki piasku (widok $\mathrm{z}$ boku)

Fig. 10. Assembly of the sand spreader (side view)

\subsection{Assembly of the sprayer for weed-control}

Fig. 11 presents the sprayer for weed-control mounted on the rear draw and buffing gear system. The method of attaching the sprayer is this same as for the spreader. The system of drive of sprayer pump is also carried out using the hydraulic motor. It is also used the so-called unification of the mechanical and hydraulic connections for both working devices. The rear draw and buffing gear system of tractor is adapted for their assembling.

\section{Technical parameters of tractor 5.1. Characteristic data of the basic tractor}

\section{Parametry techniczno-eksploatacyjne/ Technical and operating parameters}

Typ silnika napędowego/ Type of driving engine

Moc max. silnika (przy $1900 \mathrm{obr} / \mathrm{min}$ )/ Maximum engine power (at $1900 \mathrm{rpm}$ )

Pojemność skokowa silnika/ Engine cubic capacity

Norma emisji spalin/ Exhaust fumes emission standard

Jałowe obroty silnika/ Engine idle revolutions

Nominalne obroty silnika/ Engine nominal revolutions

Max. obroty silnika/ Maximum engine revolutions
6068 HRT 90D

\section{$116 \mathrm{~kW}$}

$6788 \mathrm{~cm}^{3}$

Stage $3 b$

$800 \mathrm{obr} / \mathrm{min} / 800 \mathrm{rpm}$

$2200 \mathrm{obr} / \mathrm{min} / 2200 \mathrm{rpm}$

$2275 \mathrm{obr} / \mathrm{min} / 2275 \mathrm{rpm}$ 
Pompa hydrauliczna zębata (uzupeł.) Bosch $-71 \mathrm{~cm}^{3}$ (5 bar)/ Hydraulic gear pump (supp.) Bosch $-71 \mathrm{~cm}^{3}$ (5 bar)

Kabina amortyzowana z klimatyzacją / Suspended cab with air conditioning

Sprzęgło główne (sterow. elektrohydraulicznie)/ Main clutch (controlled electrohydraulic)

Kolumna kierownicza/ Steering column

Hamulce na przednim i tylnym moście/ Brakes on the front and rear bridges

wielotarczowe, mokre/multidisc,

Alternator o natężeniu / Current of alternator

\subsection{Parametry techniczne ciągnika szynowo-drogowego/ Technical parameters of rail-road vehicles}

Parametry eksploatacyjne/ Operating parameters

Min. Siła uciagu na drodze/na torze/ Min.pull force on the road/on the track

Dopuszczalna liczba wagonów ( $80 \mathrm{Mg}$ ) holowanych na torze poziomym, z hamowaniem pneumatycznym/ Permissible number of wagons $(80 \mathrm{Mg})$ towing on the horizontal track with pneumatic braking

Dopuszczalna liczba wagonów $(80 \mathrm{Mg}$ ) holowanych na torze poziomym, bez hamowania pneumatycznego/ Permissible number of wagons $(80 \mathrm{Mg})$ towing on the horizontal track without pneumatic braking

Dopuszczalna prędkość jazdy po torze prostym z wagonami, z hamowaniem pneumatycznym/Permissible speed of ride on the straight track with wagons with pneumatic braking

Dopuszczalna prędkość jazdy po torze prostym z wagonami, bez hamowania pneumatycznego/ Permissible speed of ride on the straight track with wagons without pneumatic braking

Dopuszczalna prędkość jazdy po łukach i rozjazdach/ Permissible speed of ride on curves and turnouts

Dopuszczalna prędkość jazdy po torze prostym bez wagonów/ Permissible speed of ride on the straight track without wagons

Dopuszczalna prędkość jazdy ciagnika po drodze/Permissible speed of ride of the tractor on the road

Min. prędkość jazdy po torze/ Minimum speed of ride on the track

Średnica toczna rolek szynowego układu jezdnego/Rolling diameter of rollers of the rail running gear system

$5 \mathrm{~km} / \mathrm{h}$

$5 \mathrm{~km} / \mathrm{h}$

$20 \mathrm{~km} / \mathrm{h}$

$40 \mathrm{~km} / \mathrm{h}$

$1435 / 1520$

$400 \mathrm{~mm}$

\section{Parametry ukladu hydraulicznego/ Parameters of hydraulic system}

Wydajność zasilania hydraulicznego sprężarki i rozrzutnika/ Efficiency of hydraulic supply of compressor and spreader

Wydajność zasilania hydraulicznego docisku rolek jezdnych/ Efficiency of hydraulic supply of ride rollers pressure 
Wydajność zasilania hydraulicznego pługa/ Efficiency of hydraulic supply of plough

Średnica tłoka cylindrów hydraulicznych/ Piston diameter of the hydraulic cylinders

Średnica tłoczyska cylindrów hydraulicznych/ Piston rod diameter of hydraulic cylinders

Skok max. tłoczyska cylindra hydraulicznego/ Maximum stroke of piston rod of hydraulic cylinders

Max. ciśnienie w układzie hydr. Sprężarki, rozrzutnika

i opryskiwacza/ Maximum pressure in the hydraulic system of compressor, spreader and sprayer

Ciśnienie max. w układzie hydr. rolek jezdnych/ Maximum pressure in the hydraulic system of riding rollers

Ciśnienie gazu w akumulatorach hydr. cylindrów rolek (górnych/dolnych)/ Gas pressure in battery of hydraulic cylinders of rollers (lower/lower)

Ciśnienie gazu w akumulatorach wspomagania silników

sprężarki, rozrzutnika i opryskiwacza/ Gas pressure in battery of supporting the engines of compressor, spreader and sprayer

\section{Parametry układu pneumatycznego hamowania/Parameters of pneumatic braking} system

Max. wydajność sprężarki przy obr. silnika 800/min/ Max. efficiency of compressor at engine revolutions $800 / \mathrm{min}$

Max. wydajność sprężarki przy obr. silnika 1500/min/ Max. efficiency of compressor at engine revolutions 1500/min

Max. prędkość obrotowa sprężarki/Max. rotational speed of compressor

Max. zapotrzebowanie mocy przez sprężarkę/Max. power consumption of the compressor

Pojemność całkowita zbiorników powietrza/Total capacity of air tanks

Czas ładowania zbiorników powietrza/ Charging time of the tanks with air

\section{Parametry pługa/ Parameters of plough}

Szerokość lemiesza/ Width of ploughshare

Wysokość lemiesza/ Height of ploughshare

Kąt ustawienia lemiesza/ Angle of positioning of plougshare

Szerokość pasa odśnieżania/ Width of a strip of removing the snow

Masa całkowita odkładnicy pługa/ Total mass of plough mouldboard

\section{Parametry rozrzutnika piasku/Parameters of sand spreader}

Pojemność zbiornika/ Tank capacity

Szerokość rozrzutu/ Width of spread

Masa rozrzutnika wraz z zabudową / Mass of spreader with the equipment

System rozrzutu/ Spread system

\section{Parametry opryskiwacza/Parameters of sprayer}

Pojemność max. zbiornika/Max. capacity of tank

Szerokość max. oprysku/Max. width of spray

Masa opryskiwacza wraz z zabudową/Mass of sprayer with equipment

Dopuszczalna prędkość robocza/Permissible operating speed

\section{Masy eksploatacyjne ciągnika/ Operating masses of tractor}

Masa ciagnika bazowego marki CLAAS ARION 620/ Mass of base tractor of CLAAS ARION 620 brand

Masa ciagnika $\mathrm{z}$ hamulcem pneumatycznym/ Mass of tractor with pneumatic brake

Masa całkowita ciagnika $\mathrm{z}$ hamulcem i z pługiem/ Total mass of tractor with brake and plough
$8-10 \mathrm{l} / \mathrm{min}$

$50 \mathrm{~mm}$

$36 \mathrm{~mm}$

$450 \mathrm{~mm}$

$14 \mathrm{MPa}$

$10 \mathrm{MPa}$

ok. $2 / 0,5 \mathrm{MPa} /$ about $2 / 0,5 \mathrm{MPa}$

ok. 3,5 i 4,5 MPa/ about 3,5 - 4,5 $\mathrm{MPa}$

$30 \mathrm{~m}^{3} / \mathrm{h}$

$54 \mathrm{~m}^{3} / \mathrm{h}$

$950 \mathrm{obr} / \mathrm{min} / 950 \mathrm{rpm}$

$7,5 \mathrm{~kW}$

$0,425 \mathrm{~m}^{3}$

$\sim 4 \mathrm{~min}$

$2870 \mathrm{~mm}$

$750 \mathrm{~mm}$

$30^{\circ}$

$2250 \mathrm{~mm}$

$250 \mathrm{~kg}$

$0,32 \mathrm{~m}^{3}$

$5 \mathrm{~m}$

$160 \mathrm{~kg}$

tarczowo-odśrodkowy/

disc-centrifugal

$350 \mathrm{dm}^{3}$

$10 \mathrm{~m}$

$160 \mathrm{~kg}$

4-8 $\mathrm{km} / \mathrm{h}$

$\sim 6,5 \mathrm{Mg}$

$\sim 8,8$

9,1 Mg 
Masa całkowita ciagnika $\mathrm{z}$ hamulcem pneum., z pługiem

i z rozrzutnikiem (bez tylnego sprzegu)/Total mass of tractor with pneumatic brake, with

plough and with spreader (without rear coupler)

\section{Zastosowane opony w ciągniku/Used tractor tyres}

Typ opon tylnych/ Type of rear tyres

480/80R38

Typ opon przednich/Type of front tyres

400/80R 28

Rozstaw opon tylnych/Distance between the rear tyres

$1560 \mathrm{~mm}$

Rozstaw opon przednich/ Distance between the front tyres

$1630 \mathrm{~mm}$

Ciśnienie w oponach tylnych/Pressure in the rear tyres

$320 \mathrm{kPa}$

Ciśnienie w oponach przednich/Pressure in the front tyres

$320 \mathrm{kPa}$

\section{Podsumowanie}

Wprowadzenie do eksploatacji trzeciej generacji ciągników szynowo-drogowych jest wynikiem prac rozwojowych prowadzonych w Instytucie Pojazdów Szynowych TABOR. W ostatnim dziesięcioleciu nastapił istotny postęp techniczny w budowie ciagników rolniczych. Wybrany z pośród analizowanych, oferowanych przez producentów ciągników, ciagnnik CLAAS ARION 620 spełnia wymagania stosowane przy adaptacji ciągników rolniczych na ciagnik szynowodrogowy.

Ciągnik ma obszerną i komfortową kabinę kierowcy wyposażoną w dodatkowe siedzisko, klimatyzację oraz amortyzację kabiny w opcji standardowej oraz bogate wyposażenie nadwozia w reflektory drogowe oraz dodatkowe lampy oświetlające otoczenie ciągnika z przodu i z tyłu, co ma duże znaczenie w eksploatacji ciagnnika w nocy ze względu na bezpieczeństwo $\mathrm{w}$ prowadzeniu prac manewrowych $\mathrm{z}$ wagonami.

Ciągnik bazowy ma konstrukcję ramową przygotowaną w części przedniej do zabudowy urządzeń budowlanych np. łyżki ładowarki, koparki lub innych urządzeń. Tę cechę konstrukcyjną ciągnika wykorzystano przy projektowaniu przedniego układu pociagowozderznego pod względem korzystnego wprowadzenia w konstrukcję ciagnnika sił wzdłużnych działających na układ pociagowo-zderzny podczas eksploatacji ciagnika na torach kolejowych.

Ciagnik wyposażono $\mathrm{w}$ jedną pompe hydrauliczna typu LS, która umożliwia równoczesne zasilanie kilku odbiorników mocy.

Ciagnik charakteryzuje się dużą niezawodnością pracy pomimo zastosowania zaawansowanych technicznie elektronicznych układów sterowania np. hydraulika siłowa.

Firma CLAAS Polska ma rozbudowaną sieć serwisową na terenie Polski i Europy.

$\mathrm{Na}$ podstawie przeprowadzonych badań symulacyjnych oraz kilkuletnich badań eksploatacyjnych ciągników marki URSUS 1212, 1222, 1224, nadzorowanych przez producenta ciagników szynowo-drogowych oraz w oparciu o badania stanowiskowe

\section{Conclusion}

Introduction to operation the third generation railroad tractors is the result of development works carried out at the Rail Vehicles Institute TABOR. In the last decade there has been a significant technical progress in the construction of agricultural tractors. The selected from among analyzed ones, offered by the producers of tractors, the tractor CLAAS ARION 620 meets the requirements used for the adjusting of agricultural tractors to the rail-road tractor.

The tractor has the spacious and comfortable driver's cab equipped with an additional seat, the air conditioning and the cab's suspension in the standard option and the rich equipment of body with the road headlights and additional lamps lighting the surroundings of the tractor at the front and back, which has the great significance in the operation of the tractor at night for safety during conducting the shunting works with wagons.

The base tractor has the frame construction prepared in the front part for assembling of the building equipment e.g. loader's bucket, excavator or other devices. This constructional feature of the tractor was used in designing of the front of the draw and buffing gear system in respect of favourable introduction into the construction of the tractor the longitudinal forces acting on the draw and buffing gear system during operation of the tractor on the railway tracks.

The tractor is equipped with a hydraulic pump of type LS which enables simultaneous power supply of a few receivers.

The tractor has a high reliability of operation, despite the use of high-tech electronic control systems, e.g. force hydraulics.

CLAAS Poland company has an extended service network in the Poland and Europe.

On the basis of carried out simulation tests and several years of operation tests of tractors of URSUS 1212, 1222,1224 brands, supervised by the tractor producer of the rail-road tractors and on the basis of stand tests carried out in IPS TABOR of a prototype of the railroad tractor made on the basis of agricultural tractor 
przeprowadzone w IPS „TABOR”, prototypu ciagnika szynowo-drogowego wykonanego na bazie ciagnika rolniczego CRYSTAL, Instytut otrzymał w 2004 roku „ŚWIADECTWO DOPUSZCZENIA DO EKSPLOATACJI TYPU POJAZDU KOLEJOWEGO" $\mathrm{Nr}$ T/2002/0196-1/04-113 wydane przez Prezesa Urzędu Transportu Kolejowego w Warszawie.

Świadectwo określa zakres wielkości parametrów technicznych opatentowanego szynowego układu jezdnego oraz parametrów trakcyjnych pojazdu, które pozostają utrzymane dla stosowanych ciagników bazowych marki URSUS, CRYSTAL, CLAAS.

$\mathrm{Na}$ fotografiach $3,4,5$ pokazano odpowiednio: ciągnik w wykonaniu na tor normalny, ciagnik w wykonaniu na tor szeroki, ciagnik na torze szerokim $\mathrm{w}$ czasie pracy manewrowej $\mathrm{z}$ wagonami do transportu zboża.
CRYSTAL, the Institute received in 2004 ,CERTIFICATE OF AUTHORIZATION OF RAIL VEHICLE TYPE FOR PLACING IN SERVICE" No T/2002/ 0196-1/04-113 issued by the President of the Office of Rail Transport in Warsaw.

The certificate defines the range of technical parameters quantity of the patented rail running gear system and the traction parameters of the vehicle, which are kept for the used base tractors of URSUS, CRYSTAL, CLAAS brands.

In photos 3, 4, 5 there are shown respectively: the tractor made for the normal track, the tractor made for the wide track, the tractor on the wide track during the shunting work with wagons for grain transportation.

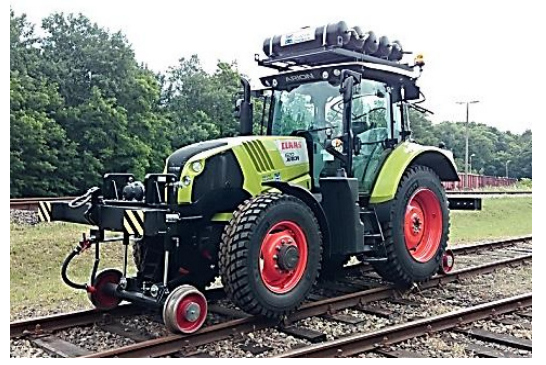

Fot. 3. Ciagnik na tor normalny

Photo 3. Tractor for the normal track

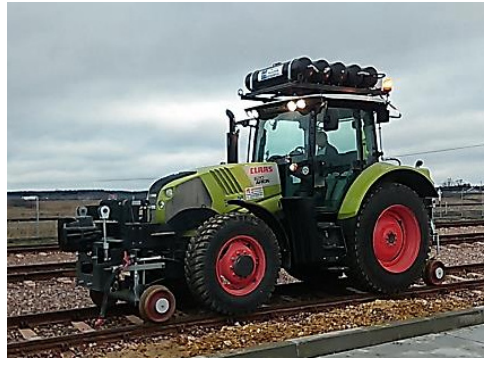

Fot. 4. Ciagnik na tor szeroki Photo 4. Tractor for the wide track

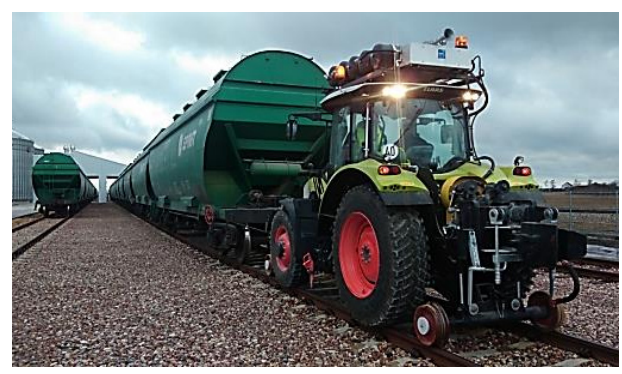

Fot. 5. Ciagnik na torze szerokim podczas pracy manewrowej z wagonami

Photo 5. Tractor on the wide track during shunting work with wagons

\section{Literatura / Bibliography}

[1] Z. Marciniak, M. Medwid; Pojazdy szynowo-drogowe. Wydawnictwo IPS TABOR Poznań 1999.

[2] M. Medwid; Hybrydowe pojazdy kolejowo-drogowe zaprojektowane i wytwarzane w Polsce. Technika Transportu Szynowego Nr 7-8/2005.

[3] M. Medwid, R. Cichy; Ciagnik szynowo-drogowy o zwiększonej wytrzymatości mechanicznej na działanie sit wzdlużnych. Pojazdy Szynowe nr 1/2010.

[4] W. Stawecki; Ocena możliwości ograniczenia negatywnego oddziaływania pojazdów szynowych na środowisko naturalne. Rozprawa doktorska - maszynopis. Poznań 2010.

[5] K. Bryk, K. Łukaszewski, M. Medwid; Analiza symulacyjna wytrzymałości elementów układów pociagowo-zderznego ciagnika szynowo-drogowego CLAAS ARION 620. OR-10741. Archiwum IPS TABOR. 